\title{
Determinants of National Savings in Pakistan: an Exploratory Study
}

\author{
Sidrat Jilani ${ }^{1}$, Salman Ahmed Sheikh ${ }^{2}$, Farooq-E-Azam Cheema ${ }^{1} \&$ Ahsan-ul-Haq Shaik ${ }^{3}$ \\ ${ }^{1}$ Institute of Business \& Technology (IBT), Karachi, Pakistan \\ ${ }^{2}$ Institute of Business Administration (IBA), Karachi, Pakistan \\ ${ }^{3}$ University of Sindh Jamshoro, Pakistan \\ Correspondence: Farooq-E-Azam Cheema, Institute of Business \& Technology (IBT), Karachi, Pakistan. E-mail: \\ dr.cheema@live.com
}

Received: February 12, 2013 Accepted: March 22, 2013 Online Published: April 27, 2013

doi:10.5539/ass.v9n5p254 URL: http://dx.doi.org/10.5539/ass.v9n5p254

\begin{abstract}
This study is an attempt to explore the impact of various factors on national savings of Pakistan including GDP, inflation, fiscal deficit and rate of interest. The study was prompted by the Word Bank report (2006) that painted showed a gloomy picture about the national savings of the country. The study is based on secondary data of the 1973-2011 periods. All variables used are found stationary except the one variable i.e. age dependency ratio. The study entails co-integration and ECM technique used mainly to find the long and short run equilibrium among the variables. The results fully supported the Johansen Co-integration and ECM tests. Result of the study concluded that GDP, inflation , and fiscal deficit play significant role in determining the national savings of Pakistan and coefficient analysis showed that growth rate and increased Government consumption give positive impact in increasing national savings while inflation possessing negative relation with national savings of the country. The coefficient results of the study show that except inflation all variables are influencing positively to national savings in the short run. It is further concluded that the speed of adjustment is $15.4 \%$ which shows that the model will correct disequilibrium position at the rate of $15.4 \%$ annually.
\end{abstract}

Keywords: national savings, GDP (gross domestic product), inflation, fiscal deficit, age dependency ratio, rate of interest

\section{Determinants of National Savings in Pakistan: An Exploratory Study}

This study is spurred by a report documented by Gallina Vinceleete of the World Bank report (2006) that has not painted a very rosy picture regarding rate of savings of the Pakistan. The report gives thudding reminder that Pakistanis are not big savers. According to this report, data of savings for 1973-2005 period place the national saving rate of Pakistan at around $14 \%$ of GDP on average and the domestic saving at $11 \%$ of output on average for the same period. While the national saving rate has been at comparable levels to the one in some of the fast growing East Asian economies, the domestic saving rate for Pakistan has been significantly lower - three times lower than the one of other rapidly growing countries in the region with similar income per capita. The analysis of this report further shows that corporate and public savings are at significantly lower level while informal channels of saving are popular in Pakistan, and their economic significance could be as large as 2 to 4 percent of output. 


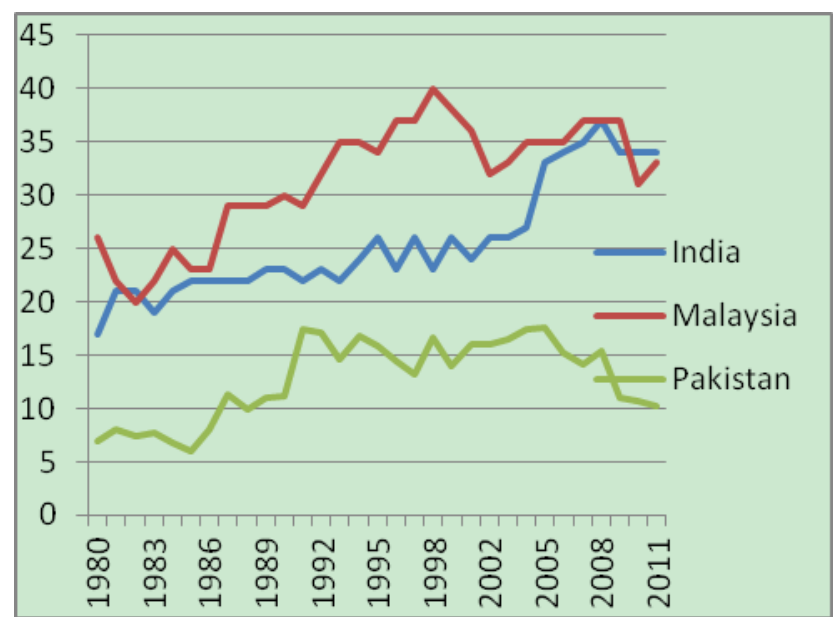

Figure 1. National savings Rate of Pakistan compared to India and Malaysia

While Pakistan's economy is in a rapid expansion with an annual output growth averaging around 6 percent for the last four years, an investment in physical and human capital is needed in order to sustain this momentum. But, as report says, the foreign direct investment (FDI) in Pakistan is still only at less than 7 percent of gross capital formation at present whereas FDI inflows to total domestic investment ratio in East Asia is generally double of this level. East Asia has sustained high growth rates in the last decades with a higher magnitude of foreign capital inflow than the one in Pakistan.

As a consequence, Pakistan has had to rely upon the third option to finance their domestic investment needs international borrowing. But the international borrowing has proved expensive to Pakistan eroding its national income base. Hence, the report concludes that if Pakistan, in the short and medium run, wants to sustain its growth and increase its investment without paying increasing shares of income in interest or dividends, it has to finance this investment by raising its domestic saving rate.

Aim of this study, in the result, is to see how national savings of Pakistan are affected by various factors like growth, inflation, interest rate, fiscal deficit and age dependency ratio in long and short run, and how the national savings can be improved through making these factors savings friendly.

The rest of the paper consists of six sections. In section II various studies are reviewed. In section III research methodology of the paper is discussed which comprises of description of econometric model, measurement of variables used, the data sources, and the econometric techniques used for this study. The results of the empirical investigation are shown in section IV. Section V consists of critical debate while the main conclusion and recommendations are explained in section VI.

\section{Literature Review}

What are the factors, which can play a major role in increasing national savings, has always been a daunting question for the economists throughout the history, most of them agree that any single factor may not be affecting rate of national savings rather it depends upon numerous factors collectively, including per capita income of country, demographics, financial liberalization, macroeconomic certainty level and fiscal policy of the country. There is vast literature on the saving pattern and determinants of savings in various countries.

To check the long run relationship of the national savings with its varios determinants Imran et al, (2010) carried out a research study in which they used CPI, remittances, public loans, govt consumption and rate of interest as major determinats of national savings and concluded that these variables posses long run relationship with national savings, somehow or other these variables are co-integrated. Furthermore, Agrwal (2001) through his study has tested cointegration on national savings rate with its selected determinants including per capita income, real interest rate and foreign savings for three countries named as Indonesia, Thiland and singapore and concluded that the selected variables are conintegrated.

Hence, we arrive at a point to construct a hypothesis a under;

$H_{1}=$ Series (National Savings, GDP, Fiscal Deficit, Inflation and rate of interest) are co-integrated.

Maddison (1992) and Bosworth (1993) have given evidence about the strong and positive relationship between 
growth and the national savings, though this connectivity varies from country to country. In case of developing countries there are many evidences that suggest that savings and growth of country are positively related. However, the causality sign between savings and growth is not clear i.e. if savings drive growth through an automatic transaction of savings into capital formation, growth gives rise to more savings (Agrwal 2001). Accordingly, various research studies have been undertaken to find the causality between growth and savings. For instance, Caroll et.al (1993) worked to find the causality between growth and savings and concluded that growth exerts positive impact on savings or put differently, savings drive growth and gives temporary boost to the GDP of a country. But question was raised by Attanasio et.al, (2000) over the finding, according to the authors (ibid), there exists bi-variate causality between savings and growth and it depends upon sample size, frequency of data and the econometric techniques used to find the causality evidence between both the variables. Agarwal (2001), in his work on the causality issue, took data from seven countries and applied Granger Causality test. His work showed that in case of most of the countries direction of causality moved form growth to savings. However, in the others, the finding turned out tobe vice versa. Hence, we arrive at a point to construct hypothesis 2 as under.

\section{H2 = Economic Growth has significant impact on National Savings.}

Inflation represents the macroeconomic uncertainty in the economy of a country. The relation between inflation and savings has two dimensions and shows two different signs. As from consumers' perception when prices of commodities increase people have to spend more on buying which decreases the rate of domestic savings. So it can be argued that there exists a negative and significant relation between inflation and domestic savings which, in turn, directly influences the national savings (Kazmi, 1993).

If the matter is taken from producers' perspective then according to Vinceleete (2006) when prices rise, producer earns more profit by charging higher prices and ultimately the phenomenon influnces the national savings positively. So from producer perspective there exists positive and significant relationship beween national savings and inflation rate. There is another study carried out by Loayza et.al, (2000) in which inflation was taken as one of the explanatory variables of private savings rate and they concluded that there exists a positive and significant relation between savings and inflation rate. Hence, we come to construct hypothesis No. 3 as under,

\section{H3 = Inflation has significant impact on National Savings}

Saving patterns of the countries are greatly affected by changes in government consumption or the income. When government revenues are less than government expenditures, it causes deficit in the budget or fiscal deficit, the effect of fiscal deficit or surplus on national savings is more in developing countries. The research studies suggest that government savings play major role in reducing fiscal deficit and the fiscal policies are designed accordingly, for example, Samwick (2000) recommended that countries which follow pay-as-go-schemes save less as compared to those countries which follow completely funded schemes. Schemidt-Hebbel (1991) estimated consumption function of thirteen developing countries in order to analyze the effects of fiscal or public policy on saving behavior and recommended that a public policy can play an important role in raising savings especially the private savings. Vinceleete (2006) concluded that tight fiscal policy is positively related to the higher savings pattern in Pakistan. The result of this work emphasizes the importance of cautious fiscal policies for country like Pakistan. Hence, the argument above leads us to the following hypothesis.

\section{H4 = Fiscal Deficit has significant impact on National Savings}

The relationship of interest rate and savings is unclear because of a paradox it follows i.e. on the one hand, it offers a positive substitution towards future consumption and simultaneously it causes negative effect on income due to high returns on saved wealth. Researchers like Mckinnon (1973) disputed the concept that increasing the interest rate increases savings resulting in boost to the economic growth. Whereas Basely et.al (1998) concluded through her study that negative income effect is dominated by positive substitution effect, hence interest rate has positive relationship with the savings. However, findings of Giovannini (1985) regarding the relationship between interest rate and savings are different as they show an insignificant relation between savings and interest rate. Agarwal (2001) through a study analyzed the savings pattern of seven Asian countries and according to him, there is variation in relationship between interest rate and savings from country to country. Like, in Malaysia, Taiwan and India there is positive relationship between interest rate and savings but impact of interest rate on savings is insignificant.

According to a study conducted by Loayza et al, (2000) that private savings are more positively affected by interested rate as compared to domestic savings. Studies have also been conducted over the sensitivity of rate of savings towards interest rate as a function of income levels. For instance, one of the studies carried out by Ogaki et.al, (1995) gives an evidence that savings give more response to interest rate in terms of rate of return at higher 
income levels. Hence, we arrive at hypothesis No. 5 of this study as under,

\section{$H 5=$ Rate of Interest has significant impact on National Savings.}

Studies on the age dependency ratio indicate that savings are also affected by demographics, including size, age and composition of households. According to the prediction of Modigliani's hypothesis; savings rate show "U" shaped pattern which means that people at the middle age save more as compared to either young or old age people. The age dependency ratio is the ratio of working age population to total population. Masson et.al (1998) concluded that the countries which have high ratio of working age population present high savings rate as compared to countries which have low ratio of working age population. As concluded from these studies countries like China are experiencing increasing savings rate as their young dependency population is increasing.

\section{Research Method}

This study is cause and effect relationship based wherein national savings is the dependent variable while GDP, inflation, fiscal deficit, rate of interest and age dependency ratio are the independent variables.

Where:

$$
N S=\beta_{1+} \beta_{2} G D P+\beta_{8} I n f+\beta_{4} F D+\beta_{5} R I+\beta_{6} A D R+\mu
$$

1) National saving is taken as the sum of private and public savings.

2) GDP (gross domestic product) indicates the sum of goods and services produced in the country in one year.

3) Inflation shows a consistent rise in price level. In this study, CPI (consumer price index) of Pakistan is taken as measure of inflation.

4) Rate of interest is taken as the real one that is the lending interest rate adjusted for inflation.

5) Fiscal deficit represents difference between the larger government consumption and the smaller revenues.

6) Age dependency ratio (ADR) is calculated by dividing the working population of country with total population All the variables are taken as percentage of GDP.

\subsection{Sources of Data}

This research is secondary and time series data based. Time series data for the 1973-2011 was used for this study to determine the impact of different factors over the national savings of the country. The data was collected from the hand book of statistics of State Bank of Pakistan and website of World Bank. The data is arranged in the Table 1below:

Table 1. Data 1973-2011

\begin{tabular}{cccccc}
\hline YEAR & $\begin{array}{c}\text { National savings } \\
\text { rate in terms of } \\
\text { GDP }\end{array}$ & $\begin{array}{c}\text { GDP (annual } \\
\text { percent) }\end{array}$ & $\begin{array}{c}\text { Inflation } \\
\text { rate }\end{array}$ & Fiscal deficit & Rate of interest \\
\hline 1973 & 12.43 & 6.89 & 23.07 & -5.43 & 5.7 \\
1974 & 8.09 & 5.19 & 30.14 & -6.62 & -21.48 \\
1975 & 6.91 & 2.68 & 27.37 & -10.76 & -16.13 \\
1976 & 11.9 & 4.06 & 11.57 & -9.5 & -2.26 \\
1977 & 13.12 & 4.07 & 8.89 & -8.5 & 0.76 \\
1978 & 15.76 & 8.33 & 7.48 & -7.81 & 4.31 \\
1979 & 13.92 & 5.24 & 8.23 & -8.81 & 0.67 \\
1980 & 14.76 & 8.15 & 9.94 & -6.24 & -1.4 \\
1981 & 17.72 & 6.47 & 14.36 & -5.41 & -5.25 \\
1982 & 16.7 & 6.56 & 11.16 & -5.3 & -1.64 \\
1983 & 19.89 & 6.88 & 4.6 & -7.04 & 4.44 \\
1984 & 17.6 & 5.41 & 7.2 & -5.99 & 0.82 \\
1985 & 15.09 & 7.39 & 5.6 & -7.79 & 3.43
\end{tabular}




\begin{tabular}{|c|c|c|c|c|c|}
\hline 1986 & 17.31 & 5.68 & 4.24 & -8.09 & 2.95 \\
\hline 1987 & 19.79 & 6.34 & 3.73 & -8.16 & 2.7 \\
\hline 1988 & 15.78 & 7.83 & 6.21 & -8.52 & 0.01 \\
\hline 1989 & 16.34 & 4.8 & 10.46 & -7.39 & -4.09 \\
\hline 1990 & 16.48 & 4.53 & 6.13 & -2.46 & 0.76 \\
\hline 1991 & 16.48 & 5.09 & 12.6 & -5.53 & -5.56 \\
\hline 1992 & 19.88 & 7.38 & 10.49 & -5.83 & -3.16 \\
\hline 1993 & 15.81 & 2.08 & 9.92 & -6.58 & -0.12 \\
\hline 1994 & 18.22 & 3.83 & 11.13 & -5.38 & -1.93 \\
\hline 1995 & 16.73 & 4.82 & 13.13 & -5.28 & -2.83 \\
\hline 1996 & 13.62 & 5.61 & 10.69 & -6.6 & 0.51 \\
\hline 1997 & 13.59 & 1.34 & 11.86 & -6.73 & 1.14 \\
\hline 1998 & 16.93 & 1.4 & 7.77 & -5.64 & 4.43 \\
\hline 1999 & 13.52 & 3.89 & 5.84 & -5.54 & 1.96 \\
\hline 2000 & 15.68 & 4.24 & 3.57 & -4.09 & 4.93 \\
\hline 2001 & 16.28 & 1.98 & 4.38 & -3.75 & 4.62 \\
\hline 2002 & 18.43 & 3.22 & 3.5 & -2.86 & 3.2 \\
\hline 2003 & 20.56 & 4.85 & 3.09 & -2.88 & 1.11 \\
\hline 2004 & 17.92 & 7.37 & 4.62 & -1.95 & -2.72 \\
\hline 2005 & 17.48 & 7.67 & 9.27 & -3.2 & -5.6 \\
\hline 2006 & 17.7 & 6.18 & 7.89 & -4.23 & -0.05 \\
\hline 2007 & 17.88 & 5.68 & 7.8 & -4.17 & 0.49 \\
\hline 2008 & 13.55 & 2 & 12.01 & -7.44 & -2.51 \\
\hline 2009 & 14.3 & 3.74 & 21.06 & -4.76 & -4.48 \\
\hline 2010 & 13.1 & 3.5 & 11.7 & -5 & 1.86 \\
\hline 2011 & 13.6 & 3.78 & 13.9 & -5.7 & -3.8 \\
\hline
\end{tabular}

Source: Website of State Bank of Pakistan and World Bank.

\subsection{Econometric Techniques}

Since, time series data in econometric are frequently found to be non-stationary containing unit root, regression estimation was not likely to show appropriate results. Accordingly, in this study:

1) First of all, Augmented Dickey Fuller (ADF) test was applied in order to find whether the time series data used in this study contained unit root

2) Secondly, the long run relationship among the independent and dependent variables was examined through application of Johansen Co-integration test.

3) In the third step Regression estimation was done on stationary variables.

4) In last step the short term dynamics of the system were determined by error correction model (ECM).

\section{Results}

\subsection{Unit Root ADF Test for Determination of Stationarity}

Findings of the order of integration showed that the age dependency ratio (ADR) had the integration of order one i.e. I(1), while fiscal deficit, GDP annual growth rate, inflation rate, national savings rate and rate of interest had the integration of order zero i.e. I (0). This order of integrations shows that only one variable i.e. age dependency ratio (ADR) was found as non stationary while all others variables including GDP, inflation rate, national savings rate and rate of interest were stationary. Accordingly, for further analysis, age dependency ratio (ADR) had to be 
dropped as co-integration analysis could only be done on those variables which possess same order of integration.

\subsection{Co-integration Test}

Co-integration Test was applied to the following hypothesis:

$H_{I}=$ Series (National Savings, GDP, Fiscal Deficit, Inflation and rate of interest) are co-integrated.

For the purpose of determination of con-integration, Johansen's test was applied, a test with all desirable statistical properties. This test was applied in order to find the long term relationship between variables. But, the age dependency ratio (ADR) variable had to be dropped because of its order one I(1) integration. According to results shown in Table 2 below $\boldsymbol{H}_{1}$ is accepted because the p value of rank test (trace) is less than the critical value i.e. 0.05 that concludes that the series is co-integrated or there exists a long run relationship among national savings, GDP, fiscal Deficit, inflation and rate of interest.

Table 2. Co-Integration test

\begin{tabular}{lllll}
\hline Unrestricted Co-integration Rank Test (Trace) & & \\
\hline Hypothesized & & Trace & 0.05 & \\
No. of CE(s) & Eigenvalue & Statistic & Critical Value & Prob.** \\
None * & $\mathbf{0 . 5 6 9 2 1 7}$ & $\mathbf{9 1 . 1 6 4 6 8}$ & $\mathbf{6 9 . 8 1 8 8 9}$ & $\mathbf{0 . 0 0 0 4}$ \\
At most $1 *$ & 0.532598 & 60.00513 & 47.85613 & 0.0024 \\
At most 2 & 0.391077 & 31.86423 & 29.79707 & 0.0285 \\
At most 3 & 0.210931 & 1.50989 & 15.49471 & 0.0974 \\
At most 4 & 0.120349 & 4.744530 & 3.841466 & 0.0294 \\
\hline
\end{tabular}

The above table shows that the null hypothesis of zero co-integrated vector is rejected against the alternative of one co-integrating vector. Similarly, null hypothesis of 'At most 1', 'At most 2' and 'At most 4' co-integrated vectors are also rejected against the alternative hypotheses.

\subsection{Regression Analysis}

In regression analysis, goodness of fit, individual significance and coefficient analysis of each independent variable and overall significance of the model were examined. Through this analysis, $\mathrm{H} 2, \mathrm{H} 3, \mathrm{H} 4$ and $\mathrm{H} 5$ were also tested.

Table 3. Regression analysis

\begin{tabular}{ccccc}
\hline Variable & Coefficient & Std. Error & t-Statistic & Prob. \\
\hline C & 19.70718 & 1.350918 & 14.58799 & 0.0000 \\
INFLATION & -0.295804 & 0.073203 & -4.040888 & 0.0003 \\
GDP & 0.331292 & 0.152955 & 2.165942 & 0.0374 \\
FD & 0.454139 & 0.149975 & 3.028109 & 0.0047 \\
RI & -0.011509 & 0.083154 & -0.138400 & 0.8907 \\
R-squared & 0.663159 & Mean dependent var & 15.66282 \\
Adjusted R-squared & 0.623530 & S.D. dependent var & 2.922190 \\
S.E. of regression & 1.792971 & Akaike info criterion & 4.124835 \\
Sum squared resid & 109.3014 & Schwarz criterion & 4.338112 \\
Log likelihood & -75.43428 & Hannan-Quinn criter. & 4.201357 \\
F-statistic & 16.73445 & Durbin-Watson stat & 1.689613 \\
Prob(F-statistic) & 0.000000 & & \\
\hline The result shows that value of adjusted $\mathrm{R}^{2}$ is 0.66 or $66 \%$ that concludes that the dependent variable i.e. national
\end{tabular}


savings is explained $66 \%$ by explanatory or independent variables i.e. inflation, GDP, fiscal deficit and the interest rate.

In order to find the overall significance of the model F-Statistics was analyzed. Table 3 above shows that the Fstatistics of the model is 16.7 which conclude the econometric model is significant. Individual significance of the variables was determined by their $t$ value. Coefficient analysis of the variables was undertaken by the values of the coefficients of the respective variables. The table shows the results for both of the analyses.

For the GDP, $t$ value remained 2.16 which show that Economic Growth (GDP) has significant impact on national savings therefore, hence $\boldsymbol{H}_{2}$ accepted. Analysis of coefficient of GDP tells us that there is positive relationship between growth and national savings it further tells us 1\% change in GDP annual growth rate will bring 33\% change in National savings rate of Pakistan.

For inflation, $\mathrm{t}$ value was found 4.04 which show that Inflation has significant impact on National savings therefore we accept $\boldsymbol{H}_{3}$. Analysis of coefficient of inflation shows there is negative association between inflation and national savings. It further shows that $1 \%$ change in inflation rate may bring decrease in $29.5 \%$ of national savings rate of the country.

For fiscal deficit, the third independent variable, "t "value remained 3.028, hence $\boldsymbol{H}_{4}$ also accepted and we concludes that fiscal deficit also has significant impact on national savings. Coefficient analysis of the fiscal deficit rate in terms of GDP shows that if there is change in fiscal deficit by $1 \%$ then it will bring change in national savings by $45.4 \%$ positively as the sign of coefficient is positive.

The $t$ value of interest rate, last independent variable, was found 0.13 which shows insignificant impact of interest rate on national savings, hence $\boldsymbol{H}_{5}$ rejected while coefficient analysis shows the negative relationship between national savings and rate of interest.

\subsection{ECM (Error Correction Model)}

Table 4 below shows result of Error Correction Model (ECM) for the short as well as long run equilibrium:

Table 4. ECM test

\begin{tabular}{cccc}
\hline Variables & Coefficient & Standard Error & (t -Ratio) \\
\hline INFLATION & -0.279497 & 0.132597 & -2.107871 \\
GDP & 0.328583 & 0.177252 & 1.853758 \\
FD & 0.456276 & 0.160443 & 2.843857 \\
RESD(-1) & 0.154631 & 0.177075 & 0.873253 \\
RI & 0.002229 & 0.141120 & 0.015798 \\
C & 19.59015 & 1.733060 & 11.30379 \\
R-squared & 0.660207 & Durbin-Watson stat & \\
Adjusted R-squared & 0.607114 & & \\
Akaike info criterion & 4.185300 & & \\
Schwarz criterion & 4.443867 & & \\
Log likelihood & -73.52071 & & \\
F-statistic & 12.43500 & & \\
Prob(F-statistic) & 0.000001 & & \\
\hline
\end{tabular}

Table 4 above shows that the value of adjusted R-squared is not greater than Durbin -Watson stat which is a good sign because it verifies the regression is not spurious regression. It also transpires from the ECM results that GDP, inflation and fiscal deficit are statically significant hence $\mathrm{H}_{2}, \mathrm{H}_{3}$ and $\mathrm{H}_{4}$ accepted for short run dynamics of the model. However, $\mathrm{H}_{5}$ is rejected since rate of interest has shown insignificant result with national savings in the short run. When the coefficient results are seen, it is concluded that except inflation all variables are influencing positively to national savings in the short run. It is further concluded that the speed of adjustment is $15.4 \%$ which shows that the model will correct disequilibrium position at the rate of $15.4 \%$ annually. 


\section{Discussion}

Results of the study show that there exist a statically significant and positive relation between savings and growth and thus verify the findings of Maddison (1992) and Bosworth (1993) results. Gallina A.Vinceleete (2006) found the same results that there is significant and positive association between annual growth rate and private savings.

Fiscal deficit which was taken as one of the determinant of national savings represents the more government consumption than its revenues. Vittori \& Schemidt-Hebbel (1991) have conducted a study on the of effect of government consumption on savings behaviour of people. And their results are same that in developing countries like Pakistan where government consumptions influences savings positively and significantly. The results of this study does not match with study made by (Gallina A.Vinceleete, 2006) however as according to that study a tight fiscal policy is recommended for Pakistan.

Analysis inflation as determinant of national savings shows that in Pakistan inflation gives significant impact on national savings but the sign is negative as it is discussed in literature that there is evidence of negative sign of inflation with national savings because domestic savings decreases with the rise of inflation which directly effects national savings (Kazmi, 1993). Results of this study do not verify the results of the study conducted by Loayza, Schmidt, \& Serven (2000) as according to them there exists positive relation between inflation and savings.

We have taken real rate of interset as one more determinant of national savings rate of Pakistan and concluded that there is negative and statically negative relation between interest rate and savings. This results of interest rate verify the study made by (Giovannini, 1985) but we must say that according to literature the effect and sign of interest rate on savings vary from country to country.

But, on the other hand result of this study regarding the relationship between interest rate and savings do not verify the study made by Mckinnon (1973) and Shaw (1973) who concluded that increase in interest rate savings increases giving boost to the economic growth. Our results verify the results of Agarwal P. (2001) however who analyzed the saving behaviour of seven Asian countries and according to his study most of the countries have shown insignificant impact of interest rate on savings.

The study concludes that the independent variables i.e. GDP, inflation, fiscal deficit and rate of interest possess long term equilibrium with national savings. Speed of adjustment or error term has come very small which means that only $15.4 \%$ adjustment will happen in each period towards long run equilibrium. Since a significant impact of growth in terms of GDP is found in the study on national savings, policies should be made to increase growth by emphasizing on improving infra structure facilities, capital development, and development in agriculture sector. All these steps will give positive impact on savings rate of Pakistan.

Study has also shown inflation having negative but significant impact on national savings, hence policies should be made to reduce inflation. Fiscal deficit represents the more consumption made by government than revenues but results show that there is positive and significant impact of fiscal deficit on national savings perhaps because when government consumption increases, it boosts economic growth, poverty reduction and also improves infrastructure which gives positive impact on national savings.

Empirical result of the last variable i.e. rate of interest shows negative and insignificant impact on national savings. It is therefore recommended that government should not rely on manipulation of interest rates in order to boost national savings.

\section{References}

Agrwal, P. (2001). The relation between savings and growth: Cointegration and Causality Evidence from Asia, Bombay. Indira Gandhi Institute of Development Research.

Attanasio, O. P., Picci, L., \& Scorcu, A. E. (2000) Savings, Growth and Investment. Review of Economics and Statistics.

Basely, T., \& Meghir, C. (1998). Do Tax Incentives Raise Private Saving? World Bank Document, Washington, D. C. Processed.

Bosworth. (1993). Savings and Investment in a Global Economy. Washington, D. C.: Brookings Institution.

Burnside, \& Craig. (1998). Private Saving in Mexico. World Bank Document, Washington, D. C.

Caroll, C., Weil, D., \& Summers, L. H. (1993). Savings and Growth: A Reinterpretation. Paper presented at the Carnegic-Rochester Public Policy Conference. Bradly Policy Research Centre April 23-24.

Denizer, C., \& Wolf, H. (2000). Aggeregate Savings in the Transitions: A Cross Country Side. The World Bank Economic Review, 481-508. 
Gallina, A. (2006). Determinants of Saving in Pakistan. A World Bank Document. (Report No. SASPR-10)

Giovannini. (1985). Savings and the Real Interest rate in LDCs. Journal of Development Economics, 197-217. http://dx.doi.org/10.1016/0304-3878(85)90054-9

Hasnain. (2006). The impact of demography, growth and public policy on household savings: A case study of Pakistan. Asia Pacific Development Journal, 13(2), 57-71.

Imran, Z. M., Abbas, M., \& Bashir, F. (2010). Short run and long run saving behaviour in Pakistan: An Empirical investigation. Eurojournals.

Kazmi. (1993). National Savings Rate of India and Pakistan: A Macroeconometric Analysis. The Pakistan Development Review, 1313-1324.

Loayza, S. K., \& Serven, L. (2000). What Drives Private Saving Across the World. Review of Economics and Statistics, 165-181. http://dx.doi.org/10.1162/003465300558678

Maddison, A. (1992). A long Run Perspective on Saving. Scandinavian Journal of Economics, 181-196. http://dx.doi.org/10.2307/3440445

Masson, B., \& Samiei. (1998). International Evidence Determinants of Private Saving. World Bank Economic Review, 483-501. http://dx.doi.org/10.1093/wber/12.3.483

Mckinnon. (1973). Money and Capital in Economic Development. Brookings Institution.

Modiglinai. (1970). The Life Cycle Hypothesis of Savings and Intercountry Differences in the Saving Ratio. In W. A. Eltis, M. F. Scott, \& J. N. Wolfs (Eds.), Introduction Growth and Trade. Clsrendon Press.

Ogaki, O., \& Reinhart. (1995). Saving Behavior in Low and Middle Income Developing Countries: A Comparison. IMF Working Paper.

Samwick. (2000). Is Pension Reform Conductive to Higher Saving? In The Review of Economic and Statistics, 264-272.

Vittorio, C., \& Hebbel, S. (1991). Public policies and saving in developing countries. Journal of Development Economics, 89-115. 